\title{
FAKTOR RISIKO DAN PROTEKTIF PEKERJA PENGGUNA NARKOBA YANG MENJALANI REHABILITASI DI BNNP JAWA BARAT
}

\author{
Rahma Dilla Arnanda, Ahmad Gimmy Prathama \\ Email: rahma13004mail@unpad.ac.id
}

\section{Fakultas Psikologi, Universitas Padjadjaran}

\begin{abstract}
Drug abuse is increasing and spreading throughout all circles, including workers. During this time many studies related to drug abuse focused on adolescents, even though workers also have a high-risk factor. Risk factor is something that can predict an increase in the likelihood of violations or mistakes later on. One step that can be done to reduce risk factors of drug abuse is to undergo rehabilitation. Therefore, this study aimed to explore the risk factors of drug abuse on workers who are undergoing rehabilitation in the Badan Narkotika Nasional Provinsi (BNNP) Jawa Barat. This study involved four drug user workers who are undergoing rehabilitation at BNNP Jawa Barat, which was obtained using convenience sampling technique. Data collection was carried out by structured interviews. This research used a qualitative approach with collective case studies design. The results showed that risk factors of drug abuse involved internal and external factors. Internal factors such low of self-esteem and difficulties to reject invitations from friends to use drugs. External factors consist of family factor, friends, environment, and socio-economic status. In addition to risk factors, researcher also found protective factors that are the user's awareness about negative impact of drug abuse and motivation for having a better life. Besides family factors, especially social support that come from their wife and work environment that demand for professionals also become a protective factor for drug abuse.
\end{abstract}

Keywords: Risk Factor, Protective Factor, Drug Abuse, Workers, BNNP Jawa Barat

\begin{abstract}
Abstrak. Penyalahgunaan narkoba semakin hari semakin meningkat dan menyebar di berbagai kalangan, termasuk pada kalangan pekerja. Selama ini banyak penelitian terkait penyalahgunaan narkoba yang berfokus pada remaja, padahal para pekerja juga memiliki faktor risiko yang tinggi. Faktor risiko adalah sesuatu yang dapat memprediksi peningkatan kemungkinan pelanggaran atau kesalahan di kemudian hari. Salah satu langkah yang dapat dilakukan mengurangi faktor risiko penggunaan narkoba adalah dengan menjalani rehabilitasi. Maka dari itu penelitian ini bertujuan untuk mengeksplorasi faktor risiko pada pekerja pengguna narkoba yang menjalani rehabilitasi di Badan Narkotika Nasional Provinsi (BNNP) Jawa Barat. Penelitian ini melibatkan empat orang pekerja pengguna narkoba yang sedang menjalani rehabilitasi di BNNP Jawa Barat, yang diperoleh dengan menggunakan teknik convenience sampling. Pengumpulan data dilakukan melalui cara wawancara terstruktur. Penelitian ini menggunakan pendekatan kualitatif dengan rancangan collective case studies. Berdasarkan penelitian, diperoleh hasil bahwa faktor risiko yang berperan terhadap penggunaan narkoba berasal dari faktor internal dan faktor eksternal. Faktor internal berupa self-esteem yang rendah dan sulitnya menolak ajakan dari teman. Adapun faktor eksternal terdiri dari faktor keluarga, teman dan lingkungan, serta keadaan sosio-ekonomi. Selain faktor risiko, peneliti juga menemukan adanya faktor protektif yang berasal dari internal pengguna berupa kesadaran akan dampak negatif dari narkoba dan keinginan akan kehidupan yang lebih baik. Selain itu faktor keluarga, terutama dukungan dari istri dan lingkungan kerja yang menuntut untuk profesional juga menjadi faktor protektif penggunaan narkoba.
\end{abstract}

\section{1 | Psychophedia Jurnal Psikologi Universitas Buana Perjuangan Karawang}


Kata Kunci: Faktor Risiko, Faktor Protektif, Penyalahgunaan Narkoba, Pekerja, BNNP Jawa Barat.

\section{Pengantar}

Narkoba adalah singkatan dari narkotika dan obat atau bahan berbahaya. Adapun dalam Undang-Undang Republik Indonesia nomor 35 tahun 2009 tentang Narkotika menjelaskan bahwa "narkotika adalah zat atau obat yang berasal dari tanaman atau bukan tanaman, baik sintesis maupun semi-sintesis, yang dapat menyebabkan penurunan atau perubahan kesadaran, hilangnya rasa, mengurangi sampai menghilangkan rasa nyeri, dan dapat menimbulkan ketergantungan, yang dibedakan ke dalam golongan-golongan sebagaimana terlampir dalam Undang-Undang ini" (Hadi, 2013). Beberapa jenis narkoba sebenarnya digunakan dalam seting medis untuk keperluan kesehatan dan untuk pengembangan ilmu pengetahuan dan teknologi, namun banyak oknum yang menyalahgunakannya. Adapun penyalahgunaan narkoba adalah penggunaan narkoba yang bukan untuk tujuan medis, pengembangan ilmu dan teknologi, melainkan untuk mendapat kenikmatan dari pengaruh narkoba tersebut. Risiko dari penyalahgunaan narkoba yaitu kecanduan pada penggunanya.

Menurut suatu penelitian, awal penyalahgunaan narkoba hingga menjadi kecanduan disebabkan oleh adanya proses belajar. Proses belajar dimulai dengan adanya kenikmatan yang diperoleh ketika mencoba narkoba, kemudian diikuti dengan munculnya kepercayaan diri. Kenikmatan dan rasa percaya diri tersebut berperan sebagai penguat perilaku (reinforcement) yang membuat pecandu ingin terus mengonsumsi narkoba (Riza, 2018).

Adapun penyalahguna narkoba di Indonesia semakin meningkat dari tahun ke tahun. Penyalahguna narkoba berasal dari berbagai macam kalangan dan usia. Hal ini dapat kita lihat dari banyaknya media yang memaparkan berita terkait dengan kasus penyalahgunaan narkoba dan survei yang dilakukan oleh lembaga-lembaga tertentu.

Penyalahgunaan narkoba tentunya memiliki banyak dampak negatif baik secara langsung terhadap kesehatan fisik dan mental ataupun secara tidak langsung. Dampak penyalahgunaan narkoba terhadap kesehatan fisik, seperti gangguan pada jantung, paruparu, dan sistem pencernaan. Adapun dampaknya terhadap kesehatan mental adalah dapat menyebabkan depresi, risiko melakukan tindak kejahatan, kekerasan, dan risiko melakukan bunuh diri. Sedangkan dampak secara tidak langsung dapat berupa terganggunya proses pendidikan, kerugian secara materil, dan tekanan dari lingkungan sosial (Humas BNN, 2014).

Pada tahun 2016, diperkirakan terdapat 275 juta orang di seluruh dunia (sekitar 5.6\% dari populasi dunia berusia 15-64 tahun) yang pernah menyalahgunakan narkoba setidaknya satu kali. Terdiri dari 192 juta pengguna ganja, 34 juta pengguna opioid, 34 juta pengguna amfetamina dan stimulan yang diresepkan, 21 juta pengguna ekstasi, 19 juta pengguna opiat, dan 18 juta kokain. Di antara sekian banyak penyalahguna, terdapat 31 juta orang yang sangat membutuhkan perawatan karena telah menderita gangguan penyalahgunaan narkoba. Menurut data WHO, setidaknya terdapat 450 ribu orang yang meninggal akibat penyalahgunaan narkoba di tahun 2015 (Indonesia: Narkoba dalam Angka Tahun 2017, 2018).

Remaja memiliki risiko tinggi terhadap penyalahgunaan narkoba. Berdasarkan pada survei penyalahgunaan dan peredaran gelap narkoba tahun 2018 yang dilakukan oleh Badan Narkotika Nasional (BNN), diperoleh angka prevalensi penggunaan narkoba di kalangan pelajar / mahasiswa sebesar 3.2\% (Badan Narkotika Nasional , 2019). Tingginya angka penyalahgunaan narkoba pada remaja ini sangat erat kaitannya dengan pencarian jati 
diri yang merupakan tugas perkembangan mereka. Dorongan pencarian jati diri yang tidak tepat sering kali menjerumuskan remaja pada masalah yang serius, seperti narkoba (Amanda, Humaedi, \& Santoso, 2017).

Selain remaja, para pekerja juga memiliki faktor risiko yang tinggi dalam penyalahgunaan narkoba. Adapun prevalensi pengguna narkoba di kalangan pekerja adalah sebesar 2.1\% (Badan Narkotika Nasional, 2019). Angka ini berkaitan dengan salah satu faktor yang dapat menyebabkan penyalahgunaan narkoba, yaitu faktor ekonomi (Amanda, Humaedi, \& Santoso, 2017). Kesulitan ekonomi atau kondisi ekonomi yang mencukupi sama-sama dapat mendorong seseorang untuk menyalahgunakan narkoba. Banyaknya tuntutan dan beban seorang pekerja juga dapat menjadi faktor risiko dalam penyalahgunaan narkoba.

Faktor risiko merupakan karakteristik, variabel, atau bahaya yang jika ada pada individu tertentu akan membuatnya lebih mengembangkan gangguan dari pada individu lain yang dipilih secara acak dari populasi umum (Mrazek \& Haggerty 1994, 12; Clayton 1992; Hawkins, Catalano dan Miller 1992; Rutter dan Garmezy 1983 dalam Arthur dkk., 2002). Faktor risiko adalah sesuatu yang dapat memprediksi peningkatan kemungkinan pelanggaran atau kesalahan di kemudian hari (Kazdin et al., 1997 dalam Towl \& Chrighton, 2010). Faktor risiko meliputi faktor individual seperti impulsivitas yang tinggi dan kecerdasan yang rendah, faktor keluarga seperti pengawasan orang tua yang buruk dan disiplin yang keras atau tidak menentu, faktor teman sebaya seperti bergaul dengan anakanak nakal, faktor sekolah seperti tingkat kenakalan yang tinggi di sekolah, faktor sosioekonomi seperti penghasilan rendah dan perumahan yang buruk, dan faktor lingkungan atau komunitas seperti tinggal di lingkungan dengan tingkat kejahatan yang tinggi (Towl \& Chrighton, 2010).
Selain faktor risiko, ada juga yang disebut dengan faktor protektif. Faktor protektif adalah faktor yang mengurangi kemungkinan perilaku bermasalah baik secara langsung atau dengan memediasi atau memoderasi pengaruh dari paparan faktor risiko (Fraser 1997; Luthar dan Zigler 1991; Masten dan Coatsworth 1998; Rutter 1987; Werner dan Smith 1992 dalam Arthur dkk., 2002). Studi longitudinal telah mengidentifikasi bahwa faktor risiko dan faktor protektif memiliki sifat prediktif, salah satunya terhadap penggunaan obat-obatan (Dryfoos 1991; Hawkins, Catalano, and Miller 1992; Hawkins et al. 1998; Lipsey and Derzon 1998; Loeber and Stouthamer Loeber 1987; Mrazek and Haggerty (dalam Arthur dkk., 2002).

Salah satu langkah kuratif yang dapat dilakukan untuk membantu penyalahguna narkoba dan mengurangi faktor risiko adalah dengan menjalani rehabilitasi. Rehabilitasi bagi pengguna narkoba juga diatur dalam Undang-Undang Republik Indonesia nomor 35 tahun 2009 tentang Narkotika BAB IX terkait dengan Pengobatan dan Rehabilitasi (Hadi, 2013). Rehabilitasi merupakan sebuah kegiatan atau proses yang membantu pecandu narkoba untuk melepaskan diri dari ketergantungan dan menyesuaikan diri serta mencapai kemampuan fisik, psikologis, dan sosial yang optimal. Rehabilitasi dapat diselenggarakan oleh instansi pemerintah maupun masyarakat (Hadi, 2013). Contoh instansi pemerintah yang menyelenggarakan rehabilitasi bagi pecandu narkoba adalah Badan Narkotika Nasional Provinsi (BNNP) Jawa Barat. BNNP Jawa Barat memiliki pelayanan rawat jalan sehingga peserta rehabilitasi tetap dapat melakukan kegiatan lainnya.

Menurut survei yang dilakukan oleh BNN, Narkoba mudah diperoleh di tempat kerja. Prevalensi penyalahgunaan narkoba paling banyak ditemukan di level pimpinan, manajer, supervisor atau mandor sebesar $2.4 \%$. kemudian diikuti oleh pekerja 
pelaksana, operator, dan staf sebesar $2.3 \%$. Sedangkan pekerja administrasi memiliki prevalensi paling rendah yaitu $1.1 \%$. BNN juga melakukan survei terhadap 5.200 pekerja yang tersebar di 9 sektor dan 13 provinsi di Indonesia. Berdasarkan survei tersebut didapatkan bahwa prevalensi penyalahgunaan narkoba paling tinggi ada di sektor berikut: 1) Angkutan, pergudangan dan komunikasi 2.8\%;

2) Jasa kemasyarakatan dan sosial perorangan $2.6 \%$; 3) Konstruksi 2.3\%; 4) Industri pengolahan $1.9 \%$; 5) Perdagangan, rumah makan dan hotel $1.8 \%$. Dari survei tersebut juga ditemukan bahwa mayoritas alasan pekerja menggunakan narkoba adalah karena ingin tahu atau coba-coba, dibujuk / diajak / dipaksa teman, dijebak dan ingin bersenangsenang. Sedangkan pekerja yang menggunakan narkoba karena alasan stres cukup sedikit (BNN \& LIPI, 2018 ).

Penelitian penyalahgunaan narkoba selama ini pada umumnya berfokus terhadap remaja. Sedangkan penelitian terkait penyalahgunaan narkoba pada pekerja masih sangat jarang dilakukan. Padahal pekerja juga memiliki banyak faktor risiko dalam penyalahgunaan narkoba karena tuntutan dan beban mereka yang besar. Hal ini perlu ditelaah lebih lanjut sebagai salah satu langkah pencegahan untuk mengurangi penyalahgunaan narkoba, terutama di kalangan pekerja. Maka dari itu penelitian ini dilakukan untuk menemukan faktor risiko penyalahgunaan narkoba pada pekerja.

Hasil penelitian ini diharapkan dapat memberikan informasi mengenai faktor risiko pada pekerja pengguna narkoba sehingga kita dapat bersama-sama memperhatikan faktor tersebut sebagai pertimbangan dalam pengambilan langkah pencegahan penyalahgunaan narkoba. Hal ini juga diharapkan dapat membantu menekan permasalahan mental yang disebabkan oleh penggunaan obat-obatan terlarang. Kemudian, hasil penelitian ini juga dapat menjadi sumbangan ilmu pengetahuan di bidang psikologi forensik terkait faktor risiko penggunaan narkoba serta dapat menjadi sumber referensi bagi penelitian selanjutnya.

\section{Metode Penelitian}

Penelitian mengenai faktor risiko penyalahgunaan narkoba pada pekerja masih jarang ditemukan sehingga informasi mengenai hal tersebut masih sangat sedikit. Maka dari itu, dalam penelitian ini peneliti menggunakan metode penelitian eksplorasi. Penelitian eksplorasi memungkinkan peneliti untuk mengetahui topik atau isu baru yang ingin dipelajari dan untuk kepentingan penelitian selanjutnya (Neuman, 2007).

Penelitian ini adalah penelitian noneksperimental dengan pendekatan kualitatif. Penelitian non-eksperimental yaitu telaah empirik sistematis di mana ilmuan tidak dapat mengontrol secara langsung variabel bebas karena menifestasinya telah muncul atau karena sifat hakikat variabel tersebut menutup kemungkinan manipulasi (Kerlinger, 2000). Adapun penelitian kualitatif yaitu pendekatan untuk mengeksplorasi dan memahami makna individu atau kelompok terhadap permasalahan (Creswell, 2014 ). Jenis penelitian kualitatif yang digunakan adalah collective case studies yang merupakan bagian dari case study. Collective case studies meliputi studi yang luas terhadap beberapa kasus individu. Tujuan utama dari collective case studies adalah memperoleh pemahaman yang lebih baik mengenai fenomena yang sedang diteliti (Christensen, 2007). Dengan menggunakan rancangan kualitatif pada penelitian ini diharapkan peneliti dapat memperoleh informasi yang luas dan mendalam terkait faktor risiko pada pekerja pengguna narkoba yang sedang menjalani rehabilitasi di BNNP Jawa Barat.

Partisipan pada penelitian ini adalah pengguna narkoba yang sedang menjalani rehabilitasi di BNNP Jawa Barat. Partisipan merupakan pekerja ketika menggunakan narkoba. Teknik pengambilan sampel yang digunakan dalam penelitian ini adalah non probability sampling, yaitu teknik 
pengambilan sampel di mana peneliti tidak dapat menjamin bahwa setiap individu di dalam populasi memiliki kesempatan yang sama untuk terpilih menjadi partisipan penelitian (Shaughnessy, B, \& S, 2012). Bentuk non probability sampling yang digunakan adalah convenience sampling. Convenience sampling merupakan pemilihan partisipan penelitian berdasarkan kepada kesediaan dan kesukarelaan individu untuk berpartisipasi (Shaughnessy, B, \& S, 2012). Dalam mendapatkan sampel, peneliti dibantu oleh pegawai BNNP Jawa Barat yang menghubungkan peneliti dengan partisipan. Pengambilan data dilakukan dengan wawancara terstruktur yang melibatkan pertanyaan-pertanyaan berdasarkan Risk and Protective Factor Constructs and Survey Scale yang disusun oleh Arthur, dkk (2002). Data yang diperoleh dianalisis secara tematik dengan mengidentifikasi tema dari data yang disampaikan partisipan. Tema yang diperoleh dapat lebih dari satu.

\section{Hasil dan Diskusi}

Pada penelitian ini, peneliti mewawancarai empat orang pekerja pengguna narkoba yang sedang menjalani rehabilitasi di Badan Narkotika Nasional (BNN) Provinsi Jawa Barat. Keempat partisipan berjenis kelamin laki-laki dengan rentang usia 36-44 tahun. Berdasarkan wawancara yang telah dilakukan, diperoleh hasil bahwa rata-rata pekerja yang menggunakan narkoba telah mulai menggunakan narkoba semenjak duduk di bangku sekolah (SMP dan SMA).

\section{Faktor Risiko}

Menurut Kazdin et al. (1997, dalam Towl \& Chrighton, 2010), faktor risiko meliputi faktor internal dan faktor eksternal. Hasil wawancara yang telah dilakukan menunjukkan bahwa faktor eksternal lebih banyak berperan sebagai faktor risiko penggunaan narkoba pada pekerja yang menjalani rehabilitasi di BNNP Jawa Barat. Adapun faktor eksternal, seperti faktor keluarga, teman, sekolah atau tempat kerja, sosio-ekonomi dan faktor lingkungan atau komunitas (Towl \& Chrighton, 2010).

Rata-rata, pekerja pengguna narkoba memiliki minimal satu orang kerabat yang juga menggunakan narkoba atau memiliki gaya hidup yang tidak baik seperti kebiasaan mengonsumsi alkohol. Selain itu, sikap orang tua yang tidak tegas dan cenderung memfasilitasi anaknya, seperti memberi uang dan mengizinkan anaknya untuk mengonsumsi alkohol atau menggunakan narkoba di rumah dengan alasan kasihan juga menjadi faktor risiko penggunaan narkoba.

Selain keluarga, faktor pertemanan dan lingkungan memiliki peran signifikan dalam risiko penggunaan narkoba. Semua partisipan penelitian memiliki lingkar pertemanan yang juga mengonsumsi narkoba. Partisipan mengetahui bahwa banyak orang di lingkungan tempat tinggalnya juga menggunakan narkoba. Partisipan mengatakan bahwa mereka memperoleh narkoba dari teman dan orang-orang yang ada di sekitar mereka. Bahkan hingga saat ini, terkadang partisipan masih menggunakan narkoba jika ada teman yang mengajak dan menyediakan barang. Pekerja pengguna narkoba juga terkadang mengonsumsi alkohol dan terlibat pada perilaku seks bebas sebelum mereka memutuskan untuk menikah.

Faktor risiko lainnya yaitu status sosioekonomi. Partisipan pada penelitian ini berasal dari status sosio-ekonomi rendah hingga tinggi dengan pendidikan terakhir SMA dan S1. Adapun pekerjaan yang mereka jalani saat ini, yaitu wiraswasta, volunteering, dan pegawai dengan rentang penghasilan 500 ribu hingga 20 juta rupiah per-bulan. Kekurangan dan kelebihan dari segi ekonomi menjadi alasan awal partisipan menggunakan narkoba. Dari hasil wawancara juga ditemukan bahwa pekerja yang menggunakan narkoba cenderung sering berpindah-pindah tempat kerja dengan alasan penghasilan yang kurang mencukupi dan kenyamanan.

Adapun faktor internal yang menjadi faktor risiko penggunaan narkoba adalah self- 
esteem yang rendah. Salah satu partisipan mengatakan bahwa ketika pertama kali menggunakan narkoba tujuannya adalah untuk meningkatkan rasa percaya diri. Sulitnya menolak ajakan dari teman atau orang-orang di sekitar juga menjadi faktor yang membuat partisipan terkadang masih menggunakan narkoba hingga saat ini. Selain itu, partisipan juga merasa bahwa pada zaman dulu mereka kekurangan sumber informasi terkait dengan dampak negatif dari penggunaan narkoba sehingga mereka mencoba berbagai macam jenis narkoba, seperti putau, sabu-sabu, ganja, dll dengan cara yang sembarangan sehingga menderita HIV dan hepatitis saat ini.

Faktor Protektif

Selain faktor risiko, ada juga yang disebut dengan faktor protektif. Faktor protektif adalah faktor yang mengurangi kemungkinan perilaku bermasalah baik secara langsung atau dengan memediasi atau memoderasi pengaruh dari paparan faktor risiko (Fraser 1997; Luthar dan Zigler 1991; Masten dan Coatsworth 1998; Rutter 1987; Werner dan Smith 1992 dalam Arthur dkk., 2002). Dari hasil wawancara, faktor protektif juga dapat dikategorikan ke dalam faktor internal dan faktor eksternal.

Kesadaran akan dampak buruk dari penggunaan narkoba merupakan faktor protektif yang utama. Partisipan merasa bahwa penggunaan narkoba hanya memberikan dampak kesenangan sesaat. Sedangkan dampak negatifnya lebih banyak dan bertahan lama. Dampak negatif dari penggunaan narkoba yang paling dirasakan oleh partisipan adalah penyakit HIV dan hepatitis yang mereka derita, menimbulkan permasalahan keluarga sehingga beberapa di antaranya mengalami perceraian, dan sangat mengganggu terhadap perekonomian hingga salah satu dari partisipan pernah mengalami gulung tikar.

Selain kesadaran akan dampak negatif dari penggunaan narkoba, partisipan juga memiliki keinginan untuk tetap hidup dengan kehidupan yang lebih baik. Hal ini mendorong mereka untuk mencari bantuan dan menjalani rehabilitasi. Selain itu, dukungan dari keluarga terutama istri juga menjadi faktor penting untuk sembuh dari ketergantungan narkoba.

Sebagian besar pekerja mengaku bahwa mereka jujur akan kondisi mereka, seperti menggunakan narkoba dan menderita penyakit HIV dan atau hepatitis kepada istri mereka sebelum menikah. Hal tersebut pun dapat diterima oleh istri mereka. Saat ini, pekerja pengguna narkoba dan keluarganya telah mengetahui dampak negatif dari penggunaan narkoba dan penyakit yang menyertainya sehingga bagi mereka yang mengidap HIV menjalani hubungan suami istri secara aman seperti menggunakan kondom. Bagi pekerja pengguna narkoba, istri juga memiliki peran yang lebih besar sebagai faktor protektif dalam keluarga dibandingkan dengan orang tua.

Adapun faktor protektif lainnya adalah lingkungan kerja. Rekan kerja partisipan tidak ada yang menggunakan narkoba dan lingkungan tempat kerja saat ini dapat membuat partisipan merasa nyaman sehingga partisipan dapat menahan keinginannya untuk menggunakan narkoba di lingkungan dan waktu kerja. Selain itu, tuntutan tempat kerja yang mengharuskan partisipan untuk profesional juga menjadi penghambat dalam penggunaan narkoba. Pada pekerjaan terakhir saat ini, partisipan sudah merasa nyaman dan cenderung ingin menetap.

Pekerja pengguna narkoba juga memiliki keinginan untuk berbagi terkait dampak negatif dari narkoba, meskipun di satu sisi merasa bahwa orang tidak akan mendengarkan mereka yang diketahui sebagai pengguna juga. Mereka tidak ingin anak muda mengalami apa yang mereka rasakan. Menurut pekerja pengguna narkoba, pada zaman dulu mereka kekurangan sumber informasi terkait dampak negatif dari narkoba sehingga mencoba segala macam jenis narkoba tanpa memikirkan dampaknya. Namun, pada zaman sekarang ini, menurut mereka informasi sudah sangat mudah didapatkan hanya saja masih 
banyak orang-orang yang mengabaikannya sehingga penyalahgunaan narkoba dan yang terkena dampak negatifnya semakin meningkat.

\section{Kesimpulan}

Pekerja pengguna narkoba telah mulai menggunakan narkoba semenjak duduk di bangku sekolah (SMP dan SMA). Adapun faktor risiko penggunaan narkoba dapat berasal dari faktor internal seperti rendahnya self-esteem dan faktor eksternal, seperti keluarga, teman, lingkungan dan sosioekonomi. Faktor eksternal merupakan faktor risiko yang memiliki peranan besar terhadap penggunaan narkoba pada pekerja. Pekerja pengguna narkoba memiliki minimal satu orang kerabat yang juga menggunakan narkoba atau memiliki gaya hidup yang tidak baik seperti mengonsumsi alkohol. Faktor internal, seperti kesadaran akan dampak negatif dari penggunaan narkoba menjadi faktor protektif utama terhadap penggunaan narkoba pada pekerja.

\section{Kepustakaan}

Amanda, M. P., Humaedi, S., \& Santoso, M. B. (2017). Penyalahgunaan Narkoba di Kalangan Remaja . Jurnal Penelitian \& PPM , 129-389.

Badan Narkotika Nasional . (2019). Indonesia Drugs Report 2019. Jakarta: Pusat Penelitian, Data dan Informasi Badan Narkotika Nasional.

BNN, \& LIPI. (2018 ). Executive Summary: Survei Penyalahgunaan dan Peredaran Gelap Narkoba Tahun 2018. Jakarta: BNN .

Christensen, L. B. (2007). Experimental Methodology 10th Edition. USA: Pearson.
Creswell, J. W. (2014 ). Research Design: Quantitative, Qualitative, and Mixed Methods Approaches. United States of America : SAGE Publication, Inc.

Hadi, I. (2013, Februari 06). Undang-Undang Nomor 35 Tahun 2009. Dipetik 12 19, 2019, dari hukumonline.com: https://www.hukumonline.com/klinik/ detail/ulasan/lt50f7931af12dc/keterkai tan-uu-narkotika-dengan-uupsikotropika/

Humas BNN. (2014, Maret 20). Dampak Langsung dan Tidak Langsung Penyalahgunaan Narkoba. Dipetik Oktober 02, 2019, dari bnn.go.id: https://bnn.go.id/dampak-langsungdan-tidak-langsung-penyalahgunaannarkoba/

Indonesia: Narkoba dalam Angka Tahun 2017. (2018). Jurnal Data Puslitdatin.

Kerlinger. (2000). Asas-Asas Penelitian Behavioral Edisi 3 Cetakan 7. Yogyakarta: Gajah Mada University Press.

Neuman, W. L. (2007). Basic of Social Research: Qualitative and Quantitative Approach Second Edition. Boston: Pearson Education, Inc.

Riza, W. L. (2018). Dinamika Psikologis pada Mantan Pecandu Napza yang Sedang Menjalani Program Subtitusi Oral Metadon (Studi Kasus). Psychophedia Jurnal Psikologi Universitas Buana Perjuangan Karawang, 15-22.

Shaughnessy, J. J., B, Z. E., \& S, Z. J. (2012). Research Methods in Psychology. New York: McGraw-Hill Companies, Inc.

Towl, G. J., \& Chrighton, D. A. (2010). Forensic Psychology . UK: BPS Blackwell. 